\title{
Pneumocystis carinii: A review of an important opportunistic pathogen in AIDS
}

\author{
M JOHN GILL, MB, FRCPC, RON READ, MD, PHD, FRCPC
}

\begin{abstract}
MJ GILL, R READ. Pneumocystis carinii: A review of an important opportunistic pathogen in AIDS. Can $J$ Infect Dis 1991;2(1):12-18. Since the first report of human infection with Pneumocystis carinii in 1942, cases of pneumonia due to this opportunistic pathogen have become increasingly common. Animal studies and clinical observations show that a significant depletion or dysfunction of $\mathrm{T}$ helper lymphocytes predisposes to clinical disease. Individuals with damaged T helper cells secondary to malignancies (eg, Hodgkin's lymphoma), drugs (eg, cyclosporine, steroids), or certain infections (eg, human immunodeficiency virus) are at particular risk. Serological studies suggest that disease is most often secondary to the reactivation of an asymptomatic infection, usually acquired during childhood. Increasing shortness of breath, a nonproductive cough and hypoxia often preceded by several weeks of lethargy, fever and weight loss are the classical features of $P$ carinii pneumonia in acquired immune deficiency syndrome. Bronchoalveolar lavage is usually the optimal diagnostic test. Immunofluorescent staining on liquified sputum induced by nebulized saline appears to be a promising and noninvasive test. Early empiric therapy with trimethoprim-sulphamethoxazole (trimethoprim $5 \mathrm{mg}$-sulphamethoxazole $25 \mathrm{mg} / \mathrm{kg} /$ day every $6 \mathrm{~h}$ ) or intravenous pentamidine ( $4 \mathrm{mg} / \mathrm{kg} /$ day) for 21 days is usually effective, but infection is not eradicated, and clinical disease is likely to recur. Prophylaxis using aerosolized pentamidine reduces the risk of pulmonary disease but can predispose to extrapulmonary infection. Improved in vitro and in vivo models of human pneumocystis infection would significantly increase understanding of the molecular biology of the organism, the pathogenesis of disease, and the optimal therapeutic regimens.
\end{abstract}

Key Words: Immunosuppression, Pneumocystis carinii, Pneumonia

\section{Pneumocystis carinii: Aperçu d'un agent pathogène oppor- tuniste important dans le syndrome d'immunodéficience acquise}

RESUME: Depuis qu'on a rapporté le premier cas d'infection humaine à Pneumocystis carinii en 1942, les cas de pneumonie due à cet agent pathogène opportuniste se sont multipliés. Les études animales et les observations cliniques montrent qu'une diminution importante ou des anomalies fonctionnelles des cellules $\mathrm{T}$ prédispose à cette affection clinique. Les personnes dont les lymphocytes helper $\mathrm{T}$ ont été endommagés consécutivement à une affection maligne (ex: lymphome de Hodgkins), à des traitements médicamenteux (ex: ciclosporine, stéroïdes) ou à certaines infections (ex: virus d'immunodéficience humaine) sont surtout sensibles. Des études sérologiques suggèrent que la maladie est le plus souvent secondaire à la réactivation d'une infection asymptomatique habituellement acquise au cours de l'enfance. Une dyspnée croissante, une toux non productive et une hypoxie succédant souvent à plusieurs semaines de léthargie, de fièvre et de perte pondérale, constituent le tableau clinique classique de la 


\begin{abstract}
pneumonie à Pneumocystis carinii dans le syndrome d’immunodéficience acquise. Le lavage bronchique est habituellement le test diagnostique optimal. La coloration immunofluorescente de l'expectoration liquéfiée provoquée par solution saline nébulisée semble être un test non invasif prometteur. Le traitement empirique précoce sous triméthoprime-sulfaméthoxazole à la dose de TMP $5 \mathrm{mg} / \mathrm{SMX} 25 \mathrm{mg} / \mathrm{kg} / \mathrm{j}$ toutes les 6 heures ou sous pentamidine $(4 \mathrm{mg} / \mathrm{kg} / \mathrm{j})$ pendant 21 jours est habituellement efficace, mais l'infection n'est pas éliminée et la maladie clinique récidivera probablement. Une aérosolthérapie prophylactique de pentamidine réduit les risques d'affection pulmonaire mais peut prédisposer à une infection extrapulmonaire. Une amélioration des modèles in vitro et in vivo de pneumocystose humaine contribuerait grandement à améliorer notre compréhension de la biologie moléculaire de l'organisme, de la pathogenèse de la maladie et des régimes thérapeutiques optimums.
\end{abstract}

$\mathrm{O}$ VER THE PAST DECADE THE INCIDENCE OF Pneumocystis carinii pneumonia has increased dramatically $(1,2)$. This changing epidemiology has principally been secondary to the epidemic of human immunodeficiency virus (HIV) infection causing the acquired immune deficiency syndrome (AIDS). In this review of $P$ carinii infection the authors will outline the current understanding of the host factors related to disease, the biology of the organism, the pathogenesis of infection, the clinical features of disease, and the recent developments in both diagnosis and therapy.

\section{BACKGROUND}

Chagas (3) originally described $P$ carinii in the lungs of guinea pigs in 1909. In a 1912 review of the works of Chagas and Carini (4), the term 'Pneumocystis carinit, was first used for this organism. The first association of $P$ carinii infection with human illness was noted in 1942 when the organism was found in malnourished debilitated children suffering from what was called 'interstitial plasma cell pneumonia' $(5,6)$. By the late 1960 s occasional cases of $P$ carinii pneumonia were seen in adults who were immunocompromised from either immunosuppressive therapy or an underlying disease (1). However, as a result of the epidemic of HIV infection the number of cases of $P$ carinii pneumonia has increased dramatically in the past decade, and is likely to continue to increase in the foreseeable future $(2,7)$. P carinii pneumonia is the initial manifestation of AIDS in $60 \%$ of cases in North America, and ultimately occurs in $85 \%$ of AIDS patients (8). It is fatal in 5 to $10 \%$ of initial episodes, and has been a major contributor to death in 25\% of AIDS cases.

\section{HOST SUSCEPTIBILITY}

Animal models and clinical observations have clearly defined that the single most critical factor in determining host susceptibility to $P$ carinii infection is $\mathrm{T}$ cell function. Models such as the severe combined immunodeficiency mouse model, the hydrocortisone-treated rat model and the nude rat model, with their varying immunodeficiencies, clearly show that the one shared critical immunodeficiency predisposing to $P$ carinii infection is impaired $\mathrm{T}$ cell function (9-11). The benefit of adoptive transfer of $\mathrm{T}$ lymphocytes to nude mice in preventing $P$ carinii pneumonia, and the absence of prophylactic or therapeutic benefit from passive immunization, further support the critical role of $\mathrm{T}$ cell function $(12,13)$. These findings are supported by the clinical observation that individuals either having malignancies causing $\mathrm{T}$ cell dysfunction or receiving immunosuppressive drugs depressing $\mathrm{T}$ cell function, along with individuals with selective depletion of $\mathrm{T}$ cells (eg, AIDS patients), have the greatest predisposition to $P$ carinii infection (14-16).

The recent epidemic of HIV infection, in which $\mathrm{T}$ cell function is relatively selectively destroyed, has provided some quantitative information on the $\mathrm{T}$ helper threshold for reactivation of $P$ carinii infection. In a large prospective study of the natural history of HIV infection among homosexual men, the incidence of $P$ carinii pneumonia was strongly associated with both the absolute $T$ helper lymphocyte cell number and the relative $\mathrm{T}$ helper cell percentage. During the study, 13\%, $24 \%$ and $39 \%$ of individuals with a T helper number of less than $200 / \mathrm{mm}^{3}$ developed $P$ carinii pneumonia by six, 12 and 36 months, respectively (17). Such information is of value both in determining the most appropriate time for intervention with prophylaxis against $P$ carinii pneumonia and in determining more likely diagnoses (18).

\section{TAXONOMY}

In the original description of $P$ carinii, Chagas (3) thought the organism was a variant of a trypanosome. However, since 1912 it has been traditionally viewed as a protozoa, due to its failure to grow on fungal media and its response to antiprotozoan drugs such as pentamidine. More recently it has been proposed that it should be classified as a fungus (19). The initial evidence to support this proposal was based on its affinity for 
fungal stains, its presumed airborne mode of spread, and its ultrastructural characteristics. More recent convincing evidence has also classified $P$ carinii as a fungus by analysis of the RNA component of the small ribosomal subunit, which is accepted as a strong marker of phylogenetic affiliations. The close affinity of the ribosomal RNA to that of fungi suggests that $P$ carinii should be classified within the fungal group (19). Such information on the likely molecular biology of the organism may be of great value in determining potential targets for antimicrobial therapy.

\section{EPIDEMIOLOGY}

Some early serological studies looking for human antibodies against $P$ carinii infection used an indirect immunofluorescent assay against intact organisms isolated from either human or rodent specimens. Other studies used an enzymelinked immunosorbent assay (ELISA) and solubilized murine $P$ carinii antigens. These studies failed to provide a consistent, convincing picture of the epidemiology of human infection $(20,21)$. Subsequent studies have shown that human- and rat-derived strains of $P$ carinii have significant antigenic differences, which may account for some of the discrepancies. More recent studies using human-specific $P$ carinii antigens suggested that the vast majority of adults have already been infected with $P$ carinii $(22,23)$. Such findings support the concept that disease from $P$ carinii is due to reactivation of a latent organism.

\section{CLINICAL FEATURES}

The symptoms and signs of $P$ carinii pneumonia are relatively nonspecific. Chronic but increasingly severe symptoms such as fever, shortness of breath and a nonproductive or mildly productive cough associated with malaise and weight loss, are common findings in $P$ carinii pneumonia (24). Characteristically symptoms have progressed over a period of several weeks to months. However, the duration of symptoms does not correlate with either the severity of the disease or the prognosis (25). The presentation of $P$ carinii pneumonia in AIDS differs significantly from that in other immunocompromised patients. AIDS patients have a significantly longer median duration of symptoms prior to presentation (28 versus five days), a lower mean respiratory rate, and a higher mean room air arterial oxygen tension (25).

Physical examination of the chest is usually surprisingly unremarkable, with only occasional nonspecific bilateral crackles found. In advanced disease, respiratory distress, cyanosis and tachypnea are common. This nonspecific presentation may be even more subtle in patients known to be
HIV positive and receiving prophylaxis against $P$ carinii infection (26). For patients who have no apparent risk of HIV infection, the presence of oral candidiasis, lymphadenopathy, hairy leukoplakia, or cutaneous lesions of Kaposi's sarcoma should alert the physician to the possible diagnosis of $P$ carinii pneumonia. In those known to be HIV infected, a T helper lymphocyte count of less than $200 / \mathrm{mm}^{3}$ also makes the diagnosis of $P$ carinii pneumonia more likely (27). However, this marker appears not to be as useful an indicator of $P$ carinii pneumonia in children seropositive for HIV (28).

\section{LABORATORY INVESTIGATIONS}

The radiological picture of $P$ carinii pneumonia is most often that of diffuse interstitial infiltrates involving all portions of the lung. Diffuse and focal airspace consolidation, cystic changes and pneumatoceles, along with cavitation, can occasionally be seen. Lobar consolidation, pneumothorax and pleural effusions have also occasionally been associated with $P$ carinii pneumonia. Approximately 5 to $25 \%$ of patients with proven $P$ carinii pneumonia have absolutely normal chest $\mathrm{x}$-rays at presentation $(25,29,30)$. The use of aerosolized pentamidine to prevent $P$ carinii pneumonia has been shown to alter the radiographic pattern if $P$ carinii pneumonia should develop. Such patients are less likely to have diffuse infiltrates and more likely to have predominant infiltrates of the upper lobe (26).

Nonspecific abnormalities in pulmonary function tests are present with $P$ carinii pneumonia. Reductions in vital capacity, total lung capacity, and single breath diffusing capacity of carbon monoxide are relatively common. An increased alveolar-arterial oxygen gradient, particularly marked on exercise, is also a common finding at presentation (31). The use of radioisotope scanning (gallium-67) has been shown to be a sensitive but nonspecific diagnostic test for $P$ carinii pneumonia (32). However, due to cost and the inherent slow nature of the test, it is seldom appropriate as a first-line diagnostic test.

\section{DIAGNOSIS}

A definitive diagnosis of $P$ carinii pneumonia can be made by the identification of the trophozoites or cysts of $P$ carinii on respiratory specimens. Traditionally, open lung biopsy or transbronchial biopsy have been the diagnostic procedures of choice for patients with $P$ carinii pneumonia (25). However, it was soon appreciated that, due to the higher parasite load often present in AIDS patients, bronchoalveolar lavage could be highly sensitive in achieving a diagnosis. The clinical specimen is often examined using a 
methanamine silver stain for $P$ carinii cysts. More recently, examination of sputum induced by nebulized 3\% saline and then liquified with dithiothreitol has proved promising as a noninvasive test (33-35). The use of monoclonal antibodies has enhanced the sensitivity of this test beyond that achieved with the traditional DiffQuik and toluidine blue 0 stains (34). In one study there were no false positive immunofluorescent stains, and a sensitivity of $92 \%$ was achieved (34). However, in patients receiving aerosolized pentamidine, one study suggested that the parasite load may be so low that transbronchial biopsy is necessary for diagnosis (26).

\section{PROGNOSTIC MARKERS}

Severe abnormalities on initial chest radiography and alveolar-arterial oxygen differences greater than $30 \mathrm{mmHg}$ have been associated with a higher mortality during the acute episode of $P$ carinii pneumonia (36). Decreased long term survival after the diagnosis of pneumonia also correlated with severity of interstitial edema on the initial biopsy, and an elevated alveolar-arterial oxygen difference. One recent study has suggested that neutrophilia greater than $5 \%$ on bronchoalveolar lavage is also a poor prognostic marker (37). The persistence of pneumocystis cysts after three weeks of therapy has also been associated with decreased long term survival (36).

\section{THERAPY}

In the treatment of acute $P$ carinii pneumonia in AIDS, 21 day regimens of either trimethoprimsulphamethoxazole (trimethoprim $5 \mathrm{mg} / \mathrm{sulpha-}$ methoxazole $25 \mathrm{mg} / \mathrm{kg} /$ day every $6 \mathrm{~h}$ ) or intravenous pentamidine ( $4 \mathrm{mg} / \mathrm{kg} /$ day) have approximately equal efficacy (38). One study, however, has suggested that survival in patients treated with trimethoprim-sulphamethoxazole may be superior to that in those treated with pentamidine (86\% versus $61 \%$, respectively) (39). Unfortunately, both pentamidine and trimethoprim-sulphamethoxazole have significant side effects, particularly in AIDS patients. The incidence of these side effects can be as high as $60 \%$. Rash, anemia, leukopenia, thrombocytopenia, nausea and vomiting occur and are seen most commonly with trimethoprim-sulphamethoxazole. With pentamidine, nephrotoxicity, hypotension, cardiac dysrhythmias and hypoglycemia are the most frequent problems $(38,39)$. Although significant, the toxicity associated with these standard regimens is rarely life threatening and can often be diminished by dose reduction, allowing the drug to be continued (39). Attempts to circumvent the toxicity of intravenous pentamidine by delivering treatment doses by inhalation have been disappointing, especially in moderate to severe $P$ carinii pneumonia $(40,41)$.

Due to the limitations of these two treatments, other therapeutic regimens have been investigated. The combination of dapsone $100 \mathrm{mg} /$ day plus $25 \mathrm{mg} / \mathrm{kg}$ every $6 \mathrm{~h}$ of oral trimethroprim for 21 days has been shown to be effective and well tolerated in patients with mild $P$ carinii pneumonia (42). The main adverse effects encountered were methemoglobinemia and anemia. A comparative trial of trimethoprim-sulphamethoxazole and trimethoprim-dapsone for treatment of mild to moderate $P$ carinii pneumonia has shown equal efficacy, with fewer adverse effects in the trimethoprim-dapsone arm (43). One open uncontrolled study has evaluated trimetrexate 30 $\mathrm{mg} / \mathrm{m}^{2} /$ day for 21 days in the treatment of patients with $P$ carinii pneumonia who could either not tolerate, or had failed to respond to, standard drug regimens (44). This preliminary study suggested that the combination of trimetrexate with leucovorin rescue $20 \mathrm{mg} / \mathrm{m}^{2}$ every $6 \mathrm{~h}$ for 23 days was safe and effective for the treatment of such patients (44). Eflornithine, an experimental drug which inhibits polyamine synthesis, has also shown early promise as therapy for patients failing conventional therapy for $P$ carinii pneumonia (45). One further uncontrolled study has suggested that clindamycin (300 to 450 mg every $6 \mathrm{~h}$ ) and daily primaquine (15 mg base) may be effective for treatment of $P$ carinii pneumonia with few side effects $(46,47)$.

Most patients on these regimens improve progressively during therapy, but some experience radiographic and clinical deterioration about five days after starting treatment. This is believed to be caused by an inflammatory response to dead or dying organisms, and usually resolves by days 7 to 10 of therapy. Switching agents on the basis of this deterioration is not advocated (48).

For patients with moderate to severe $P$ carinii pneumonia (arterial-alveolar gradient greater than $35 \mathrm{mmHg}$ or a partial pressure of oxygen less than $70 \mathrm{mmHg}$ on room air), a consensus panel has recommended the early adjunctive use of systemic corticosteroids to reduce the likelihood of death, respiratory failure and deterioration in oxygenation (49). A dose of prednisone $40 \mathrm{mg}$ bid (days 1 to 5), reduced to $20 \mathrm{mg}$ bid (days 6 to 10 ), and finally stopping after a dose of $20 \mathrm{mg}$ daily between days 11 and 21, was used in the largest study supporting the use of steroids (50). Other studies also support the early use of steroids in seriously ill patients $(51,52)$. However, the potential value of steroids in patients failing conventional therapy after $12 \mathrm{~h}$ is unknown, and ongoing 
clinical surveillance for adverse effects in patients receiving steroids is recommended (50).

\section{PROPHYLAXIS}

Despite receiving antiviral therapy such as zidovudine, approximately $60 \%$ of AIDS patients suffer from a relapse of $P$ carinii pneumonia within the first year after diagnosis (18). This high attack rate has caused a variety of different drugs to be studied for use as secondary prophylaxis to prevent relapse of $P$ carinii pneumonia, as well as primary prophylaxis for patients at highest risk of $P$ carinii pneumonia ( $\mathrm{T}$ helper count less than $200 / \mathrm{mm}^{3}$ or less than $20 \%$ ).

Primary prophylaxis with trimethoprim-sulphamethoxazole $(160 \mathrm{mg}$ trimethoprim/800 mg sulphamethoxazole) administered twice daily with leucovorin rescue (5 mg daily) successfully prevented $P$ carinii disease in a placebo controlled trial of AIDS patients with Kaposi's sarcoma (53). Unfortunately, $17 \%$ of patients had to discontinue therapy due to unacceptable side effects, and 50\% had some form of adverse effect. Other drugs such as pyrimethamine-sulphadoxine, dapsone or dapsone-trimethoprim have been proposed as prophylactic agents, but await proper evaluation in controlled trials $(54,55)$.

Aerosolized pentamidine has been accepted as providing both primary and secondary prophylaxis against $P$ carinii pneumonia, and has been licensed for use in the United States (18). One approved dose is $300 \mathrm{mg}$ every four weeks administered by a nebulizer meeting a certain set of standards (usually a Respirgard II Jet Nebuliser [Marquest, Colorado]); this recommendation has been supported by a recent randomized controlled trial comparing $30 \mathrm{mg}$ every two weeks, $150 \mathrm{mg}$ every two weeks, and $300 \mathrm{mg}$ once monthly (56). In Canada, for secondary prophylaxis after a large

\section{REFERENCES}

1. Walzer PD, Perl DP, Krogstad DJ, Rawson PG, Schultz MG. Pneumocystis carinii pneumonia in the United States. Epidemiologic, diagnostic, and clinical features. Ann Intern Med 1974;80:83-93.

2. Mills J. Pneumocystis carinii and Toxoplasma gondii infections in patients with AIDS. Rev Infect Dis 1986;8:1001-11

3. Chagas C. Nova tripanozomiaza humana. Mem Inst Oswaldo Cruz 1909;1:159-218.

4. Delanoe P, Delanoe M. Sur le rapport des kystos de carinii de Trypanosoma lewisi. Compt Rend Acad Sci 1912;155:658-60.

5. Van de Meer G, Brug SL. Infection à pneumocystis chez l'homme et chez les animax. Ann Soc Belg Med Trop 1942:22:301-7.

6. Vanek J, Jirovec O. Parasitaere Pneumonia. Interstitielle plasmazelleu pneumonie der Fruehgeborener verursacht durch Pneumocystis
Canadian multicentre trial, a second approved dose of pentamidine $(60 \mathrm{mg}$ every other week after an induction period of $60 \mathrm{mg}$ on five days during the first two weeks) administered by an ultrasonic nebulizer (FISONEB ${ }^{\mathrm{TM}}$ ) has been licensed for use (57).

At present the optimal dosage and form of prophylaxis is not yet determined, but prophylaxis in some form is currently recommended for all individuals with a $\mathrm{T}$ helper count less than 200 cells $/ \mathrm{mm}^{3}$ and $/$ or $20 \%$ of total lymphocytes (18).

\section{EXTRAPULMONARY DISEASE}

$P$ carinii can cause infections other than $P$ carinii pneumonia in patients with impaired $\mathrm{T}$ cell function. P carinii has been shown to cause infections in the skin, liver, thyroid, bone marrow and retina (58-65). Many but not all such patients had received aerosolized pentamidine. This form of drug administration may achieve adequate drug concentrations in the lung, but subtherapeutic levels elsewhere. $P$ carinii should be suspected in any HIV-infected individual who presents with unexplained multisystem disease, particularly if he or she is receiving aerosolized pentamidine.

\section{SUMMARY}

As the number of individuals with impaired immunity from HIV infection increases, it is inevitable that $P$ carinii will become a common infection in clinical practice. Unfortunately, an inadequate understanding of the pathogenesis of infection and a limited ability to study the organism in vitro and in vivo have hindered the development of safe and effective measures for prophylaxis and therapy. However, improved diagnostic and therapeutic approaches are currently being developed which offer promise in the control of this disease.

carinii. Abl Bakt 1952;158:120-7.

7. Masur H, Lane C, Kovacs JA, Allegra CJ, Edman

JC. Pneumocystis pneumonia: From bench to clinic. Ann Intern Med 1989; 11 1:813-26.

8. Murray JF, Felton CP, Carey SM, et al. Pulmonary complications of the acquired immune deficiency syndrome. N Engl J Med 1984;30:1682-8.

9. Walzer PD, Powell RD Jr, Yoneda K. Experimental Pneumocystis carinii pneumonia in different strains of cortisonized mice. Infect Immun 1979:24:939-47.

10. Frenkel JK, Good JT, Shultz JA. Latent pneumocystis infection of rats: Relapse and chemotherapy. Lab Invest 1966;15:1559-77.

11. Walzer PD, Schnelle V, Armstrong D, Rosen PP. Nude mouse - a new experimental model for Pneumocystis carinii infection. Science 1977; 197:177-9.

12. Furuta T, Vedd K, Kyuwa S, Fujiwara K. Effect of T 
cell transfer on Pneumocystis carinii infection in nude mice. Jpn J Exp Med 1984;54:57-64.

13. Hughes WT, Kim HK, Price RA, Miller C. Attempts at prophylaxis for murine Pneumocystis carinii pneumonitis. Curr Ther Res 1973;15:581-7.

14. Walzer PD, Schultz JG, Western KA, Robbins JF. Pneumocystis carinii pneumonia and primary immune deficiency disease. Natl Cancer Inst Monogr 1976;43:65-74.

15. Gold E. Infections associated with immunologic deficiency disease. Med Clin North Am 1974;58:649-59.

16. Burke BA, Good RA. Pneumocystis carinii infection. Medicine (Baltimore) 1973;52:23-51.

17. Polk BF, Fox R, Brookmeger R, et al. Predictors of acquired immunodeficiency syndrome developing in a cohort of seropositive homosexual men. N Engl J Med 1987;316:61-6.

18. Centres for Disease Control. Guidelines for prophylaxis against Pneumocystis carinii pneumonia for persons infected with the human immunodeficiency virus. MMWR 1989;38 (Suppl 5): 1-9.

19. Edman JC, Kovacs JA, Masur H, Santi DV, Elwood JH, Sogin ML. Ribosomal RNA sequence shows Pneumocystis carinii to be member of the fungi. Nature 1988;334:519-22.

20. Norman L, Kagan IG. Some observations on the serology of Pneumocystis carinii infections in the United States. Infect Immun 1973;8:317-21.

21. Tanabe K, Furuta T, Veda K, Tanaka H, Shimada K. Serological observations of Pneumocystis carinii infection in humans. J Clin Microbiol 1985;22:1058-60.

22. Peglow SL, Smulian G, Linke MJ, et al. Serologic responses to Pneumocystis carinii antigens in health and disease. J Infect Dis 1990;161:296-306.

23. Kovas JA, Halpern JL, Swan JC, Moss J, Parillo $\mathrm{JE}$, Masur H. Identification of antigens and antibodies specific for Pneumocystis carinii. J Immunol 1988; 140:2023-31.

24. Hopewell PC. Pneumocystis carinii pneumonia: Diagnosis. J Infect Dis 1988;157:1115-9.

25. Kovacs JA, Hiemenz JW, Madier AM, et al Pneumocystis carinii pneumonia: A comparison between patients with the acquired immune deficiency syndrome and patients with other immunodeficiences. Ann Intern Med 1984; 100:663-71.

26. Jules-Elysee KM, Stover DE, Zaman MB, Bernard EM, White DA. Aerosolised pentamidine: Effects, diagnosis and presentation of Pneumocystis carinii pneumonia. Ann Intern Med 1990;1 12:750-7.

27. Phair J, Munoz A, Detels R, et al. The risk of Pneumocystis carinii pneumonia among men infected with human immunodeficiency virus type I. N Engl J Med 1990;322:161-5.

28. Leibowitz E, Rigaud M, Pollack H, et al. Pneumocystis carinii pneumonia in infants infected with the human immunodeficiency virus with more than 450 CD4 T lymphocytes per cubic millimeter. N Engl J Med 1990;323:531-3.

29. Goodman PC, Daley C, Minagi H. Spontaneous pneumothorax in AIDS patients with Pneumocystis carinii pneumonia. Am J Radiol 1986;147:29-31.

30. Barrio JL, Sucerez M, Rodriguez JL, Saldana MJ, Pitchenik AE. Pneumocystis carinii pneumonia presenting as cavitating and noncavitating solitary pulmonary nodules in patients with AIDS. Am Rev Respir Dis 1986;134:1094-6.

31. Stover DE, White DA, Romano PA, Gellene RA, Robeson WA. Spectrum of pulmonary diseases associated with the acquired immune deficiency syndrome. Am J Med 1985;78:429-37.

32. Coleman DL, Hattner RS, Luce JM, Dodek PM, Golden JA, Murray JF. Correlation between gallium lung scans and fibreoptic bronchoscopy in patients with suspected Pneumocystis carinii pneumonia and AIDS. Am Rev Respir Dis 1984; 130: 1 166-9.

33. Leigh TR, Parsons B, Hume C, Husain OAW, Gazzard B, Collins JV. Sputum induction for diagnosis of Pneumocystis carinii pneumonia. Lancet 1989;ii:205-6.

34. Kovacs JA, Ng VL, Masur H, et al. Diagnosis of Pneumocystis carinii pneumonia improved detection in sputum with use of monoclonal antibodies. N Engl J Med 1988;318:589-93.

35. Zaman Nk, Wooten OJ, Surrakmanga B, et al. Rapid noninvasive diagnosis of Pneumocystis carinii from induced liquefied sputum. Ann Intern Med 1988;109:7-10.

36. Brenner M, Ognibene FP, Lack EE, et al. Prognostic factors and life expectancy of patients with AIDs and $P$ carinii pneumonia. Am Rev Respir Dis $1987 ; 136: 1199-206$.

37. Mason GR, Hashimoto CH, Dickman PS, Foutty LF, Lobb CJ. Prognostic implications of bronchoalveolar lavage neutrophilia in patients with $P$ carinii pneumonia and AIDS. Am Rev Respir Dis 1989; 139: 1336-42.

38. Wharton JM, Coleman DL, Wofsy CB, et al. Trimethoprim-sulfamethoxazole or pentamidine for Pneumocystis carinii pneumonia in the acquired immunodeficiency syndrome. Ann Intern Med 1986; 105:37-44.

39. Settler FR, Cowan R, Nielson DM, Ruskin J. Trimethoprim-sulfamethoxazole compared to pentamidine for $P$ carinii pneumonia in AIDS. A prospective non-crossover study. Ann Intern Med 1988; 109:280-7.

40. Soo Hoo GW, Mohsenifar Z, Meyer RD. Inhaled or intravenous pentamidine therapy for Pneumocystis carinii pneumonia in AIDS. Ann Intern Med 1990; 113:195-202.

41. Conte JE, Chernoff D, Feigal DW, et al. Intravenous or inhaled pentamidine for treating Pneumocystis carinii pneumonia in AIDS. Ann Intern Med 1990;113:203-9.

42. Leoung GS, Mills J, Hopewell PC, Hughes W, Wofsy C. Dapsone-trimethoprim for Pneumocystis carinii pneumonia in the acquired immunodeficiency syndrome. Ann Intern Med 1986;105:45-8.

43. Medina I, Mills J, Leoung G, et al. Oral therapy for Pneumocystis carinii pneumonia in the acquired immunodeficiency syndrome. A controlled tiral of trimethoprim-sulfamethoxazole versus trimethoprim-dapsone. N Engl J Med 1990;323:776-82.

44. Allegra CJ, Chabmer BA, Tuazon CU, et al. Trimetrexate for the treatment of Pneumocystis carinii pneumonia in patients with acquired immune deficiency syndrome. N Engl J Med 1987;317:978-85.

45. Smith D, Davies S, Nelson M, et al. Pneumocystis 
carinii pneumonia treated with eflornithine in AIDS patients resistant to conventional therapy. AIDS 1990;4:1019-21.

46. Toma E, Fourner S, Poisson M, et al. Clindamycin with primaquine for Pneumocystis carinii pneumonia. Lancet 1989;i:1046-8.

47. Toma E, Fourner S, Poisson M, et al. Clindamycin/primaquine for Pneumocystis carinii pneumonia in AIDS. Vth International Conference on AIDS, Montreal 1989. (Abst)

48. Davey RT, Masur H. Recent advances in the diagnosis, treatment, and prevention of Pneumocystis carinii pneumonia. Antimicrob Agents Chemother 1990;34:499-504.

49. National Institutes of Health - University of California expert panel for corticosteroids as adjunctive therapy for pneumocystis pneumonia. Consensus statement on the use of corticosteroids as adjunctive therapy for pneumocystis pneumonia in the acquired immunodeficiency syndrome. N Engl J Med 1990;323:1500-4.

50. Bozzette SA, Settler FR, Chits J, et al. A controlled trial of early adjunctive treatment with corticosteroids for Pneumocystis carinii pneumonia in the acquired immunodeficiency syndrome. N Engl J Med 1990;323:1451-7.

51. Gagnon S, Boota AM, Fischl MA, Baier H, Kirksey OW, LaVoie L. Corticosteroids as adjunctive therapy for severe Pneumocystis carinii pneumonia in the acquired immune syndrome. N Engl J Med 1990;323:1444-50.

52. Montaner JSG, Lawson LM, Levitt N, et al. Corticosteroids prevent early deterioration in patients with moderately severe Pneumocystis carinii pneumonia and the acquired immunodeficiency syndrome (AIDS). Ann Intern Med 1990; 113:14-20.

53. Fischl MA, Dickinson GM, Lavoie L. Safety and efficacy of sulfamethoxazole and trimethoprim chemoprophylaxis for Pneumocystis carinii pneumonia in AIDS. JAMA 1988;259:1185-9.

54. Pearson RD, Hewlett EL. Use of pyrimethamine- sulfadoxine in prophylaxis against chloroquineresistant Plasmodium falciparum and Pneumocystis carinii. Ann Intern Med 1987;106:714-8.

55. Hughes WT. Comparison of dosages, intervals, and drugs in the prevention of Pneumocystis carinii pneumonia. Antimicrob Agents Chemother 1988;32:623-5.

56. Leoung GS, Feigal DW, Montgomery AB, et al. Aerosolized pentamidine for prophylaxis against Pneumocystis carinii pneumonia. N Engl J Med 1990:323:769-75.

57. Montaner JSG, Lawson LM, Gervais A, et al. A placebo controlled study of aerosol pentamidine for the secondary prophylaxis of AIDS-related $P$ carinii pneumonia. Ann Intern Med. (In press)

58. Coulman C, Greene I, Archibald WR. Cutaneous pneumocystosis. Ann Intern Med 1987;106:396-8.

59. Kwok S, O'Donnell JJ, Wood IS. Retinal cotton wool spots in a patient with Pneumocystis carinii infection. N Engl J Med 1982;307:184-5.

60. Raviglione MC, Mamuz P, Sugar J, Mullen MP. Extrapulmonary pneumocystis infection. Ann Intern Med 1989;111:339. (Lett)

61. Richie TL, Yamaguchi E, Virani NA, Quinn BD, Chaisson RE. Extrapulmonary pneumocystis infection. Ann Intern Med 1989;111:339-40. (Lett)

62. Davey RT, Margolis D, Kleiner D, Deyton L, Travis W. Digital necrosis and disseminated Pneumocystis carinii infection after aerosolized pentamidine prophylaxis. Ann Intern Med 1989;1 11:681-2.

63. Poblete RB, Rodriguez K, Foust RT, Reddy R, Saldane MJ. Pneumocystis carinii hepatitis in the acquired immune deficiency syndrome. Ann Intern Med 1989;110:737-8.

64. Gallant JE, Enriguez RE, Cohen KL, Hammers LW. Pneumocystis carinii thyroiditis. Am J Med 1988;84:303-6.

65. Schinella RA, Breda SD, Hammerschlag PE. Otic infection due to Pneumocystis carinii in an apparently healthy man with antibody to the human immunodeficiency virus. Ann Intern Med 1987; 106:399-400. 


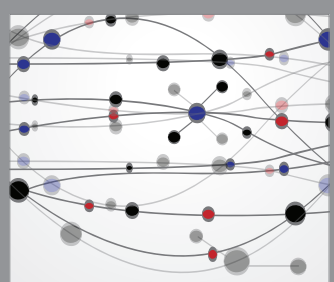

The Scientific World Journal
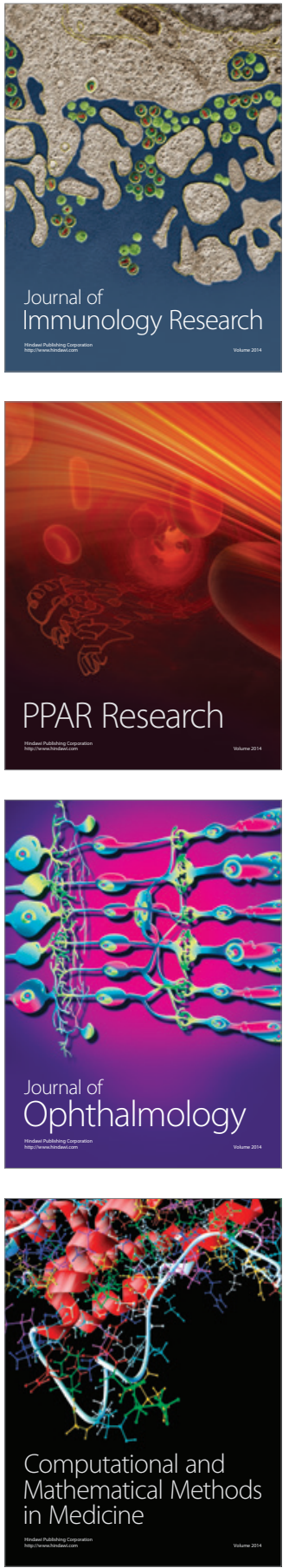

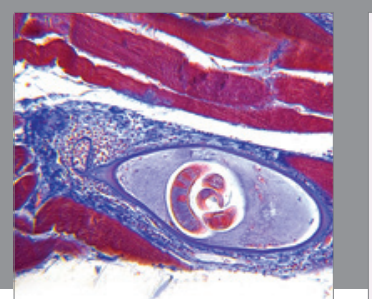

Gastroenterology Research and Practice

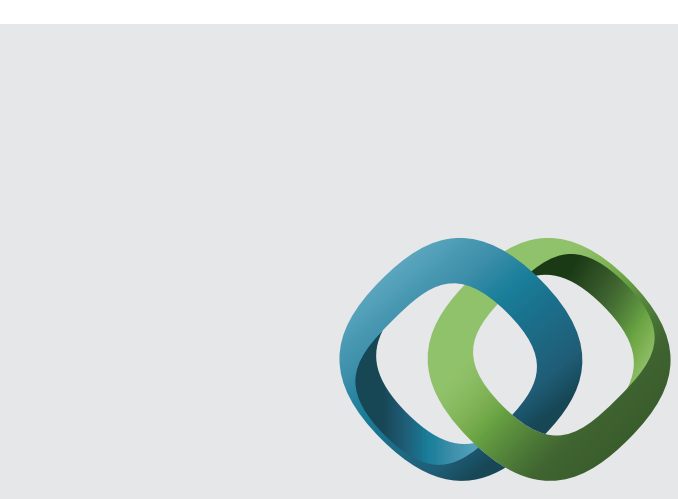

\section{Hindawi}

Submit your manuscripts at

http://www.hindawi.com
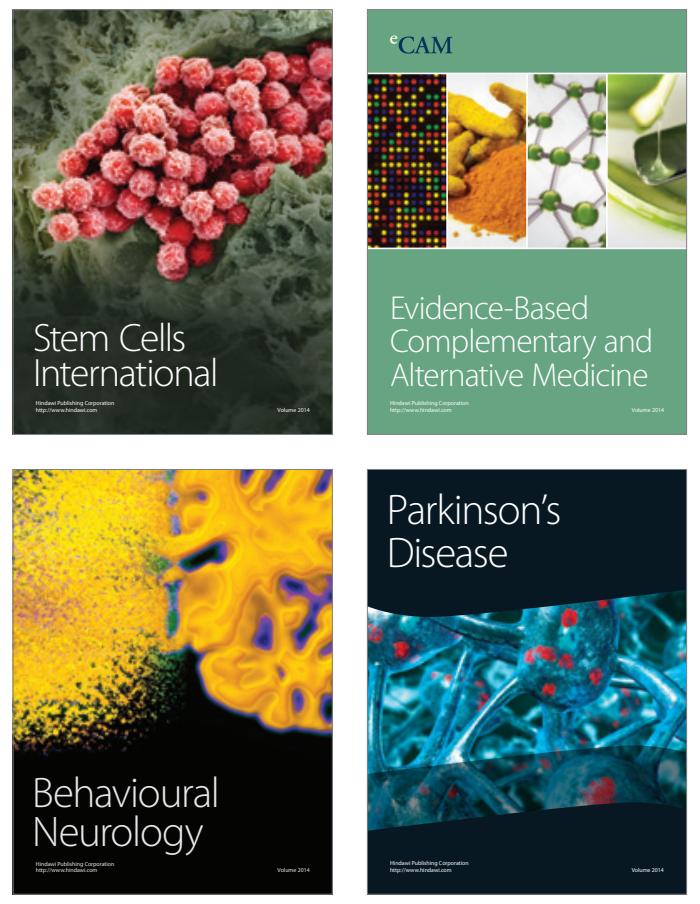
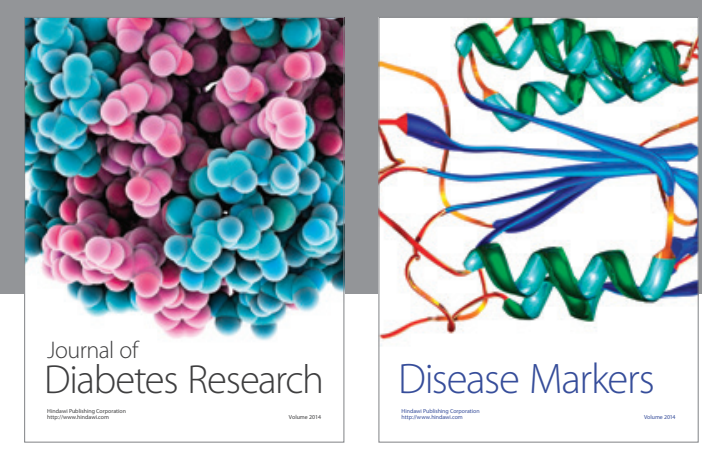

Disease Markers
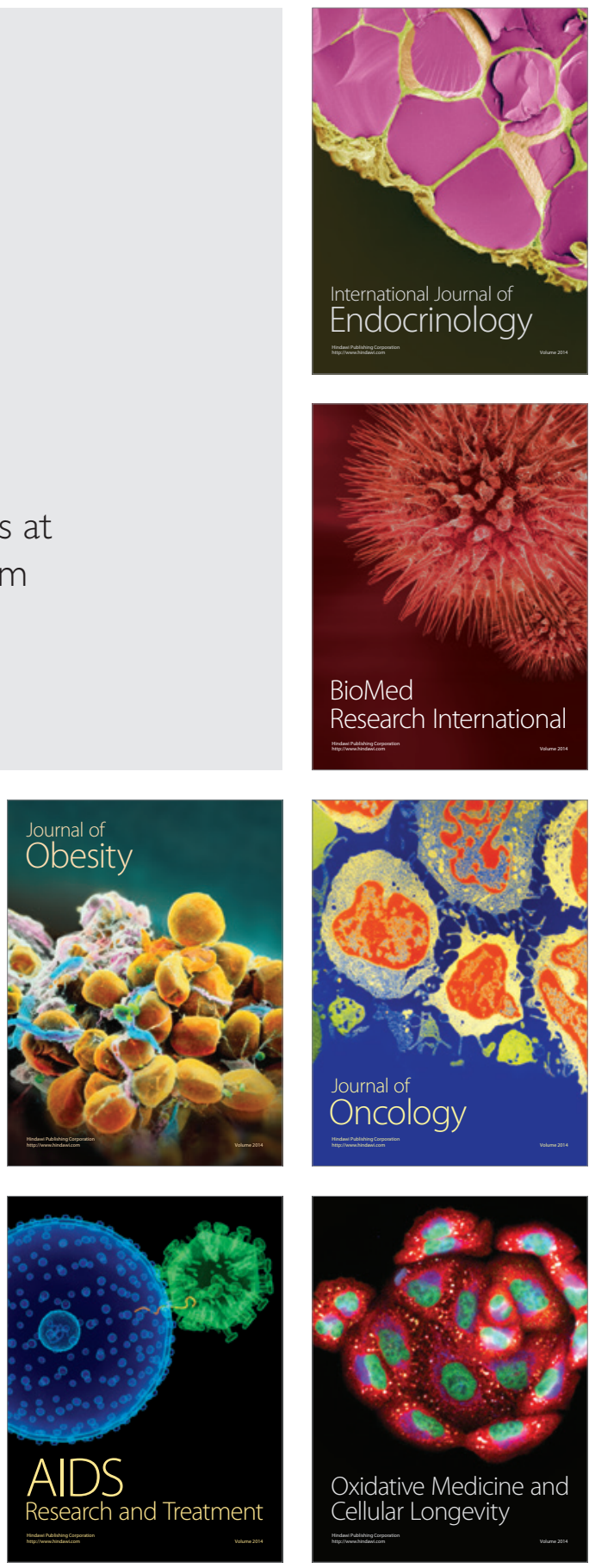